UDC 368

JEL: G22, F15, F63, F65

\section{Maryna Demianchuk}

$\mathrm{PhD}$ of Economics, Associate

Professor,

Odessa I.I. Mechnikov National

University,

Odessa, Ukraine

E-mail: ma-demyanchuk@ukr.net orcid.org/0000-0002-3907-3464

\section{Bekhruzkhon \\ Hislatxon \\ o'g'li Makhamadaliev \\ Management Development Institute of Singapore in Tashkent (MDIST), \\ Tashkent, Uzbekistan \\ E-mail: bexruz17@mail.ru \\ orcid.org/0000-0002-7975-5160}

\section{Viacheslav Kotlubai}

$\mathrm{PhD}$ in Economic Sciences, Associate Professor, National University "Odessa Law Academy", Odessa, Ukraine

E-mail: v.o.kotlubay@gmail.com orcid.org/0000-0002-4560-7063

\section{Helen Shramko}

Senior Lecturer, Odessa Institute of Trade and

Economics, University of Trade and Economics,

Odessa, Ukraine

E-mail: shrame165@gmail.com orcid.org/0000-0002-0404-9333

Received: August, 2019

Accepted: September, 2019

DOI:10.31520/2616-7107/2019.3.3-7

(C) Economics. Ecology. Socium, 2019 CC BY-NC 4.0 license

\section{THE INFLUENCE OF GLOBALIZATION AND INTEGRATION PROCESSES ON THE ACTIVITY OF INSURANCE ORGANIZATIONS}

Introduction. The activity of each market entity is associated with the risk that must be prevented and reduced by the insurance target. World experience shows that wellestablished insurance business actively contributes to business development and solving social problems. The degree of insurance development is an indicator of the maturity of market relations.

Aim and tasks. The purpose of the study is to determine the impact of globalization and integration processes on the activities of insurance organizations.

Results. Therefore, the analysis of the world and insurance market of Ukraine was conducted in the work, which made it possible to establish that the latter is in a difficult situation, but a positive trend of its development exists. The problems of development of insurance organizations are revealed and the measures for their solution in the conditions of the present with the use of correlationregression modeling are argued. The identified factors that slow down the development of insurance in Ukraine are presented by such groups as economic, organizational-legal, functional, information-analytical and social-psychological. On the basis of correlation-regression modeling and taking into account the trends of functioning of the domestic and world markets of insurance services, as well as taking into account the most acute problems faced by the market of insurance services of Ukraine, the priorities for promoting the development of the insurance market of Ukraine in order to overcome the influence of adverse factors have been established.

Conclusions. On the basis of the conducted researches concerning determination of influence of globalization and integration processes on activity of insurance organizations it can be stated that the insurance market of Ukraine is at the stage of development and integration into the world space. Despite certain achievements, it is characterized by shortcomings, the presence of which shows the prospects for development and, thus, the potential for Ukraine. Taking into account the trends of functioning of the domestic and world markets of insurance services, as well as taking into account the most acute problems faced by the market of insurance services of Ukraine, the priorities for promoting the development of the insurance market of Ukraine were established in order to overcome the influence of adverse factors.

Keywords: globalization, integration, trends and problems of insurance market development, insurance organization, correlation-regression modeling. 


\section{УДК 368}

JEL: G22, F15, F63, F65

\section{Марина Дем'янчук}

Кандидат економічних наук, доцент,

Одеський національний

університет імені I.I. Мечникова, Одеса, Україна

E-mail: ma-demyanchuk@ukr.net orcid.org/0000-0002-3907-3464

\section{Бехрузхон Хіслатсон огглі Махамадалісв}

Інститут розвитку менеджменту Сінгапуру в Ташкенті (MDIST),

Ташкент, Узбекистан

E-mail: bexruz17@mail.ru orcid.org/0000-0002-7975-5160

\section{Вячеслав Котлубай}

кандидат економічних наук, доцент, Національний університет «Одеська юридична академія» Одеса, Україна

E-mail: v.o.kotlubay@gmail.com orcid.org/0000-0002-4560-7063

\section{Олена Шрамко}

старший викладач, Одеський торговельно-економічний інститут торговельно-економічного університету Одеса, Україна E-mail: shramel65@gmail.com orcid.org/0000-0002-0404-9333

Отримано: Серпень, 2019 Прийнято: Вересень, 2019

DOI:10.31520/2616-7107/2019.3.3-7

(C) Економіка. Екологія. Соціум, 2019 CC BY-NC 4.0 ліцензія

\section{ВПЛИВ ГЛОБАЛІЗАЦІЙНИХ ТА ІНТЕГРАЦІЙНИХ ПРОЦЕСІВ НА ДІЯЛЬНІСТЬ СТРАХОВИХ ОРГАНІЗАЦІЙ}

Вступ. Діяльність кожного суб'єкта ринкових відносин пов'язана 3 ризиком, який необхідно попереджувати та зменшувати, на що спрямовано страхування. Світовий досвід показує, що добре налагоджена страхова справа активно сприяє розвитку бізнесу та вирішенню соціальних проблем. Ступінь розвитку страхування $є$ індикатором зрілості ринкових відносин.

Мета і завдання. Метою дослідження є виявлення впливу глобалізаційних та інтеграційних процесів на діяльність страхових компаній.

Результати. У роботі проведено аналіз світового та страхового ринку України, який дозволило встановити, що останній знаходиться у скрутному становищі, однак позитивна тенденція його розвитку існує. Розкрито проблематику розвитку страхових організацій та аргументовано заходи щодо їх вирішення в умовах сьогодення із застосуванням кореляційно-регресійного моделювання. Виявлені фактори, які уповільнюють розвиток страхування в Україні, представлено такими групами як економічні, організаційно-правові, функціональні, інформаційно-аналітичні та соціальнопсихологічні. На основі кореляційно-регресійного моделювання та зважаючи на огляд тенденцій функціонування вітчизняного та світового ринків страхових послуг, а також ураховуючи найбільш гострі проблеми, 3 якими стикається ринок страхових послуг України, встановлено пріоритети сприяння розвитку страхового ринку України 3 метою подолання впливу несприятливих факторів.

Висновки. На основі проведених досліджень щодо визначення впливу глобалізаційних та інтеграційних процесів на діяльність страхових організацій можна стверджувати, що страховий ринок України перебуває на етапі розвитку та інтеграції у світовий простір. Незважаючи на певні здобутки він характеризується недоліками, наявність яких показує перспективи розвитку i, таким чином, потенціал для України. Зважаючи на огляд тенденцій функціонування вітчизняного та світового ринків страхових послуг, а також ураховуючи найбільш гострі проблеми, 3 якими стикається ринок страхових послуг України, встановлено пріоритети сприяння розвитку страхового ринку України 3 метою подолання впливу несприятливих факторів.

Ключові слова: глобалізація, інтеграція, тенденції та проблематика розвитку страхового ринку, страхова організація, кореляційно-регресійні моделювання. 
Introduction. However, one of the most prominent phenomena of our time, which is increasingly attracting the attention of researchers, is the globalization and informatization of society. In these circumstances, there is an increase in international trade, an increase in the scale and pace of capital movements, information exchange and so on. All this happens around the clock in real time in the global financial markets thanks to modern technologies and the Internet, which have allowed overcoming the distance, borders and time to exchange assets, ideas and scientific innovations.

\section{Analysis recent research and} publications. Theoretical and methodological bases of functioning of the market of insurance services and organization of activity of insurance companies on it, the study of issues of the current state of the insurance market, the nature and role of insurance, prospects for further development, devoted to the work of such domestic and foreign scientists and practitioners as: Sibirskaya, E., Khokhlova, O., Oveshnikova, L., Tulinova, E. [1], Tikhomirov, N., Tikhomirova, T., Khamitov, E., Ponomarev, V. [2], and other scientists who fruitfully work on the solution of economic, financial and public administrations of the insurance market. In paying due attention to the existing developments and not diminishing their importance, attention should be paid to assessing trends and problems of functioning of the world and domestic insurance services market in the context of changing the paradigm of its development, as well as outlining ways to unify domestic practice of insurance business with international in order to maintain its competitiveness financial environment.

Aim and tasks. The purpose of the study is to determine the impact of globalization and integration processes on the activities of insurance organizations, the achievement of which necessitated the following major tasks: 1) identify trends in the world and insurance market of Ukraine; 2) identify problems of development of insurance organizations of Ukraine; 3) identify measures to address the problematic issues of the development of insurance organizations with the use of correlation-regression modeling.
Results. Given the difficult conditions in the country's political and economic sphere, the issue of protecting business participants from potential threats and negative factors is of particular importance. In order to avoid the risk or minimize it in the world practice, insurance is used as a way to compensate for the economic losses caused by natural disasters, industrial accidents, catastrophes, protect the interests of individuals and legal entities in the event of adverse and unforeseen events, etc. Today, insurance is one of the strategic sectors of the economy, because it contributes to the accumulation of savings in the form of insurance premiums and turning them into investments.

Not only does insurance have a compensatory function, but it also contributes to a large number of macroeconomic tasks of the state. Thus, it can be argued that the basis for achieving social harmony, a high standard of living, and the stability of the national reproductive process is a perfect system of insurance protection.

Non-life (re)insurance continues to operate in soft market conditions. Premiums charged by nonlife (re)insurers in the commercial lines, property and catastrophe markets remain under pressure, partly due to continuously increasing competition and losses incurred by natural catastrophes in 2017. Capital levels (especially for reinsurers) are solid given the market's high capacity. Alternative capital continued to significantly increase, reaching record levels.

Prolonged low interest rates are a source of vulnerability for life insurers. Profitability is still under stress, especially given products with embedded guarantees. An abrupt rate rise is a potential disruptive risk, which could lead to policy lapses and surrenders.

Global commercial insurance prices increased in Q2 2018 for the third consecutive period, driven mainly by increases in property, financial and professional lines. The 2017 GIMAR identified the low-yield environment as the main threat to the stability of the global insurance market, especially for companies offering long-term guaranteed rates on their products as they are prone to asset liability mismatch risk [3]. 


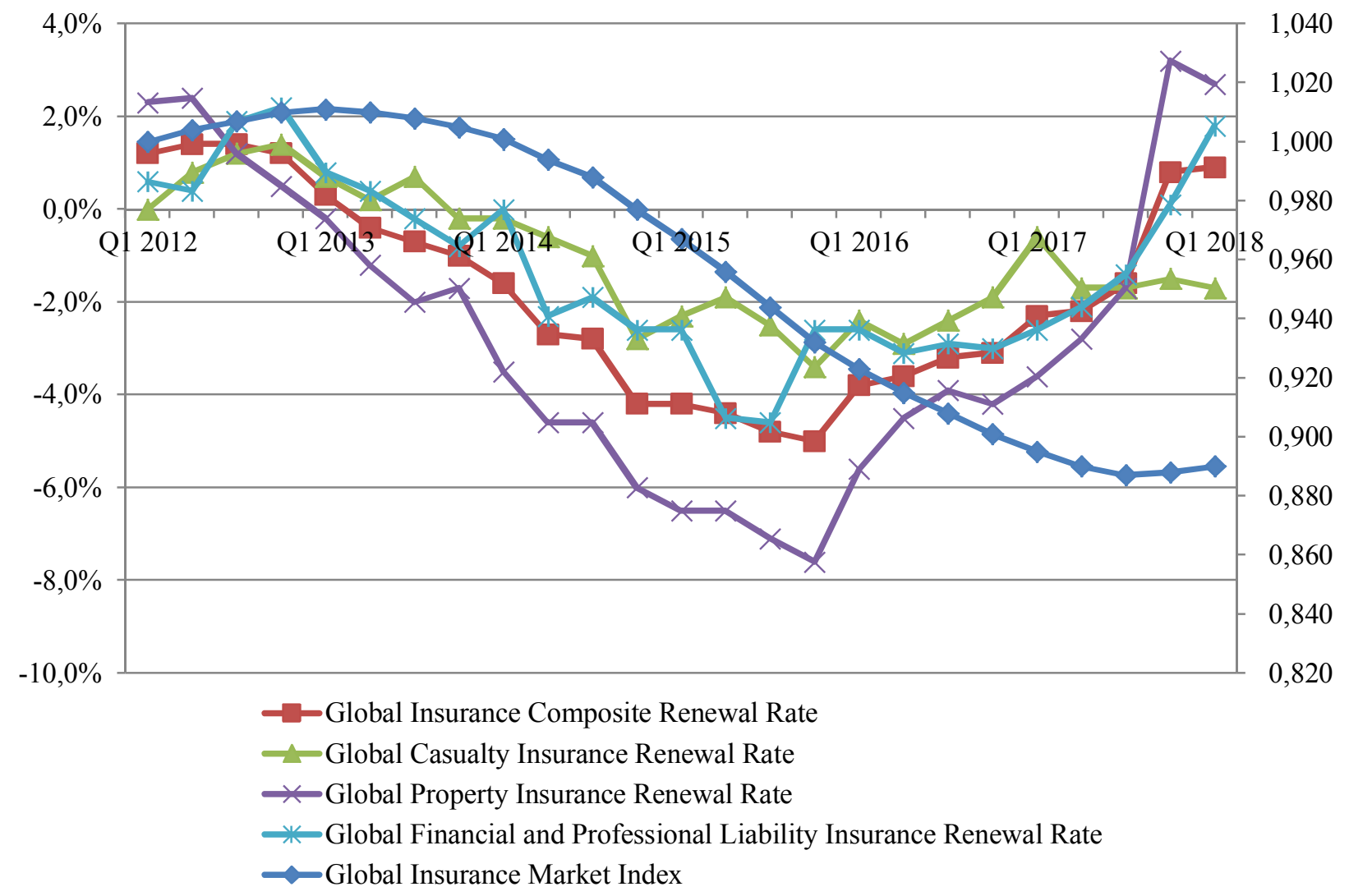

Source: created by the author on the base of [4].

The insurance market is the second largest in the capital market among other non-banking

The share of the Ukrainian insurance market financial markets in Ukraine.

Table 1. Share of the Ukrainian insurance market in GDP for 2008-2018

\begin{tabular}{|c|c|c|c|c|c|c|c|c|c|c|c|}
\hline \multirow{2}{*}{ Indicators } & \multicolumn{11}{|c|}{ Years } \\
\hline & 2008 & 2009 & 2010 & 2011 & 2012 & 2013 & 2014 & 2015 & 2016 & 2017 & 2018 \\
\hline $\begin{array}{l}\text { GDP, million } \\
\text { UAH }\end{array}$ & 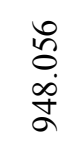 & $\begin{array}{l}\frac{n}{m} \\
\stackrel{m}{\sigma} \\
\sigma\end{array}$ & 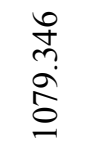 & $\begin{array}{l}\bar{\sigma} \\
\text { } \\
\text { ปे }\end{array}$ & 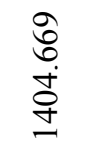 & $\begin{array}{l}\infty \\
\stackrel{2}{\vec{n}} \\
\stackrel{b}{J}\end{array}$ & 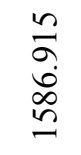 & 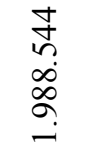 & 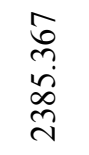 & $\begin{array}{l}\infty \\
\infty \\
\infty \\
\infty \\
\curvearrowright \\
\curvearrowright\end{array}$ & $\begin{array}{l}\stackrel{2}{2} \\
\infty \\
\infty \\
n \\
n\end{array}$ \\
\hline $\begin{array}{c}\text { Gross } \\
\text { insurance } \\
\text { premiums, } \\
\text { million UAH }\end{array}$ & $\underset{\stackrel{o}{+}}{+}$ & 竎 & 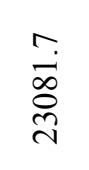 & 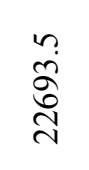 & 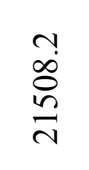 & $\begin{array}{l}\vec{a} \\
\vec{b} \\
\stackrel{0}{\sim}\end{array}$ & $\begin{array}{l}? \\
\frac{6}{6} \\
\stackrel{0}{N}\end{array}$ & స̊ & $\frac{n}{\stackrel{n}{n}}$ & $\frac{\infty}{\stackrel{\infty}{+}}$ & $\begin{array}{l}n \\
\tilde{b} \\
\approx \\
\sigma\end{array}$ \\
\hline $\begin{array}{c}\text { Insurance } \\
\text { market unit } \\
\text { weight in GDP, } \\
\%\end{array}$ & $\hat{n}$ & $\underset{\sim}{\stackrel{+}{i}}$ & $\underset{⿱ 亠}{\Delta}$ & $\stackrel{n}{\stackrel{n}{g}}$ & $\stackrel{n}{n}$ & $\stackrel{2}{2}$ & oे & $\stackrel{n}{n}$ & f & $\stackrel{\text { I }}{\stackrel{0}{-}}$ & ભે \\
\hline
\end{tabular}

Source: created by the author on the base of [5].

The table shows that over the last decade, the share of the insurance market in GDP has decreased by almost $1 \%$ and in 2018 is equal to $1.39 \%$. This indicator is very small compared to other spheres of economic activity.
The total number of insurance companies as of December 31, 2018 was 281, including IC "life"1 - 30 companies, IC "non-life" - 251 companies, (as for December 31, 2017 - 294 companies, including IC "life" - 33 companies, IC "non-life" - 261 companies) [6]. 
The state of the insurance market, its level of integration and needs is characterized by the volume of insurance premiums and insurance payments. Of great importance in the stability of the insurance market is the level of capitalization of insurers, that is, the amount of own funds and insurance reserves. The main indicators of the insurance market and its dynamics are presented in Table. 2.

Table 2. Main indicators of the insurance market activity and its dynamics

\begin{tabular}{|c|c|c|c|c|c|}
\hline \multirow[b]{2}{*}{ Indicators } & \multicolumn{3}{|c|}{ Years } & \multicolumn{2}{|c|}{ Growth rate, $\%$} \\
\hline & 2016 & 2017 & 2018 & $\begin{array}{l}2017 / \\
2016\end{array}$ & $\begin{array}{l}2018 / \\
2017\end{array}$ \\
\hline 1 & 2 & 3 & 4 & 5 & 6 \\
\hline \multicolumn{6}{|c|}{ Number of insurance contracts concluded during the reporting period, thousand pieces } \\
\hline $\begin{array}{l}\text { Number of contracts, except compulsory accident insurance } \\
\text { contracts for transport, including: }\end{array}$ & 61272.8 & 70658.2 & 77495.0 & 15.32 & 9.7 \\
\hline - with insurers-individuals & 42534.6 & 66915.2 & 72460.2 & 57.32 & 8.3 \\
\hline $\begin{array}{l}\text { Number of compulsory personal accident insurance } \\
\text { contracts for transport }\end{array}$ & 118198.4 & 114824.7 & 123582.5 & -2.85 & 7.6 \\
\hline \multicolumn{6}{|c|}{ Insurance activity, million } \\
\hline Gross insurance premiums, including: & 35170.3 & 43431.8 & 49367.5 & 23.49 & 13.7 \\
\hline - life insurance & 2756.1 & 2913.7 & 3906.1 & 5.72 & 34.1 \\
\hline Gross insurance payments, including: & 8839.5 & 10536.8 & 12863.4 & 19.20 & $22 . .1$ \\
\hline - life insurance & 418.3 & 556.3 & 704.9 & 32.99 & 26.7 \\
\hline Gross payments, $\%$ & 25.1 & 24.3 & 26.1 & - & - \\
\hline Net insurance premiums & 26463.8 & 28494.4 & 34424.3 & 7.67 & 20.8 \\
\hline Net insurance payments & 8561.0 & 10256.8 & 12432.6 & 19.81 & 21.2 \\
\hline Net payout rate, $\%$ & 32.3 & 36.0 & 36.1 & - & - \\
\hline \multicolumn{6}{|c|}{ Reinsurance, million UAH } \\
\hline Paid for reinsurance, including: & 12668.7 & 18333.6 & 17940.7 & 44.72 & -2.1 \\
\hline - to reinsurers resident & 8706.4 & 14937.4 & 14943.2 & 71.57 & 0.0 \\
\hline - to non-resident reinsurers & 3962.3 & 3396.2 & 2997.5 & -14.29 & -11.7 \\
\hline Payments offset by reinsurers, including: & 1233.2 & 1208.2 & 2459.0 & -2.03 & 103.5 \\
\hline - resident reinsurers & 278.5 & 280.0 & 430.8 & 0.54 & 53.9 \\
\hline - non-resident reinsurers & 954.7 & 928.2 & 2028.2 & -2.78 & 188.5 \\
\hline Insurance premiums received from non-resident reinsurers & 40.1 & 46.1 & 48.4 & 14.96 & 5.0 \\
\hline Payments offset by non-resident reinsurers & 14.2 & 13.8 & 44.4 & -2.82 & 221.7 \\
\hline \multicolumn{6}{|c|}{ Insurance reserves, million UAH } \\
\hline The volume of insurance reserves formed & 20936.7 & 22864.4 & 26975.6 & 9.21 & 18.0 \\
\hline - life insurance reserves & 7828.2 & 8389.6 & 9335.1 & 7.17 & 11.3 \\
\hline - technical reserves & 13108.5 & 14474.8 & 17640.5 & 10.42 & 21.9 \\
\hline \multicolumn{6}{|c|}{ Insurers' assets and share capital, million } \\
\hline $\begin{array}{l}\text { Total assets of insurers (according to Form } 1 \text { (Ukrainian } \\
\text { Accounting standard 2) }\end{array}$ & 56075.6 & 57381.0 & 63493.3 & 2.33 & 10.7 \\
\hline $\begin{array}{l}\text { Assets defined in Art. no. } 31 \text { of the Law of Ukraine "About } \\
\text { Insurance" for the presentation of insurance reserves }\end{array}$ & 35071.9 & 36084.6 & 40666.5 & 2.89 & 12.7 \\
\hline Volume of paid-up share capital & 12661.6 & 12831.3 & 12636.6 & 1.34 & -1.5 \\
\hline
\end{tabular}

Source: created by the author on the base of [6].

The table shows that the increase in gross insurance premiums occurred in almost all types of insurance. The share of net insurance premiums in gross premiums for 2018 is $69.7 \%$. The volume of gross insurance payments / indemnities in comparison with 2017 increased by UAH 2326.6 million. (22.1\%), the volume of net insurance payments increased by UAH 2 175.8 million. $(21.2 \%)$. The increase in the volume of gross insurance payments for 2017 took place in the majority of the main systemforming types of insurance. The structure of gross and net insurance premiums for 20152018 is presented in Table. 3 . 
Table 3. Structure of gross and net insurance premiums for 2015-2018

\begin{tabular}{|c|c|c|c|c|c|c|c|c|}
\hline \multirow{3}{*}{ Types of insurance } & \multicolumn{8}{|c|}{ Insurance premiums, million UAH } \\
\hline & \multicolumn{2}{|c|}{2015} & \multicolumn{2}{|c|}{2016} & \multicolumn{2}{|c|}{2017} & \multicolumn{2}{|c|}{2018} \\
\hline & gross & net & gross & net & gross & net & gross & net \\
\hline $\begin{array}{l}\text { Auto Insurance (Comprehensive } \\
\text { Cover, CCLI, Green Card) }\end{array}$ & 7871,6 & 7322,4 & 9277,5 & 8653,0 & 10613,0 & 9858,1 & 12975,1 & 11720,7 \\
\hline Life insurance & 3555,4 & 1255,4 & 2756,1 & 2754,1 & 2913,7 & 2913,7 & 3906,1 & 3906,1 \\
\hline $\begin{array}{l}\text { Health Insurance (Continuous } \\
\text { Health Insurance) }\end{array}$ & 3486,2 & 2188,1 & 2355,5 & 2280,2 & 2881,3 & 2673,9 & 3486,7 & 3243,1 \\
\hline Property insurance & 3598,6 & 2172,9 & 4142,4 & 2633,3 & 5098,9 & 2578,5 & 6440,2 & 3222,0 \\
\hline Financial risk insurance & 2186,6 & 2186,6 & 3596,7 & 1985,4 & 5594,4 & 1829,5 & 5135,5 & 1663,8 \\
\hline Third party liability insurance & 1977,6 & 1292,1 & 2093,9 & 1430,6 & 2925,0 & 1613,2 & 2567,2 & 1659,7 \\
\hline $\begin{array}{l}\text { Insurance against fire and natural } \\
\text { hazards }\end{array}$ & 1929,2 & 1862,1 & 2551,9 & 1782,1 & 3598,1 & 1576,1 & 4497,1 & 1915,6 \\
\hline Accident insurance & 2059,6 & 1391,5 & 837,1 & 727,2 & 1308,5 & 1002,9 & 1754,2 & 1329,0 \\
\hline Cargo and baggage insurance & 535,5 & 442,7 & 4374,6 & 1264,2 & 4686,7 & 1001,4 & 2899,0 & 1479,3 \\
\hline Medical expenses insurance & 490,7 & 469,2 & 727,0 & 671,3 & 891,0 & 833,2 & 1345,9 & 1098,8 \\
\hline Aviation insurance & 348,7 & 200,2 & 501,1 & 482,7 & 764,3 & 662,8 & 1041,7 & 778,5 \\
\hline Credit insurance & 449,0 & 426,9 & 531,0 & 505,7 & 365,0 & 334,7 & 1113,6 & 577,2 \\
\hline Other types of insurance & 1173,8 & 1073,4 & 1340,1 & 1218,3 & 1705,8 & 1531,5 & 2205,2 & 1830,5 \\
\hline Total & 29736,0 & 22354,9 & 35170,3 & 26463,8 & 43431,8 & 28494,4 & 49367,5 & 34424,3 \\
\hline
\end{tabular}

The table shows that net premiums grew structure of gross and net insurance payments by $20.8 \%$ or UAH $5,929.9$ million in 2017 . The for $2015-2018$ is presented in Table. 4.

Table 4. Structure of gross and net insurance payments for 2015-2018

\begin{tabular}{|c|c|c|c|c|c|c|c|c|}
\hline \multirow{4}{*}{\begin{tabular}{|l}
\multicolumn{1}{|c}{ Types of insurances } \\
$\begin{array}{l}\text { Auto Insurance (Comprehensive Cover, CCLI, Green } \\
\text { Card) }\end{array}$
\end{tabular}} & \multicolumn{8}{|c|}{ Insurance payments, million UAH } \\
\hline & gross & net & gross & net & gross & net & gross & net \\
\hline & \multicolumn{2}{|c|}{2015} & \multicolumn{2}{|c|}{2016} & \multicolumn{2}{|c|}{2017} & \multicolumn{2}{|c|}{2018} \\
\hline & $3,187.2$ & $3,077.6$ & $3,868.3$ & $3,707.5$ & $4,997.8$ & $4,802.9$ & $5,831.6$ & $5,623.8$ \\
\hline Life insurance & $1,195.5$ & $1,197.8$ & 935.4 & 822.8 & $1,879.2$ & $1,803.6$ & $2,095.4$ & $2,094.9$ \\
\hline Health Insurance (Continuous Health Insurance) & 169.2 & 169.1 & 149.7 & 149.4 & 262.5 & 260.6 & $1,423.6$ & $1,412.4$ \\
\hline Property insurance & $1,402.6$ & $1,257.3$ & 418.3 & 418.3 & 556.3 & 556.3 & $1,585.0$ & $1,393.4$ \\
\hline Financial risk insurance & 116.4 & 114.7 & $1,101.7$ & $1,101.7$ & 261.3 & 261.3 & 312.8 & 311.5 \\
\hline Third party liability insurance & 434.1 & 429.3 & 81.9 & 81.4 & 167.2 & 165.1 & 262.4 & 249.7 \\
\hline Insurance against fire and natural hazards & 491.6 & 491.6 & 216.8 & 216.1 & 263.5 & 261.4 & 122.1 & 119.3 \\
\hline Accident insurance & 302.6 & 302.6 & $1,341.4$ & $1,339.9$ & 1,672 & $1,671.6$ & 78.0 & 78.0 \\
\hline Cargo and baggage insurance & 109.8 & 106.4 & 392.8 & 392.5 & 66.1 & 63.9 & 447.6 & 444.7 \\
\hline Medical expenses insurance & 688.5 & 456.4 & 333.2 & 331.4 & 410.9 & 410.1 & $12,863.4$ & $12,432.6$ \\
\hline
\end{tabular}

Source: created by the author on the base of [6].

The gross insurance payments for 2018 amounted to UAH 12863.4 million, including from insurance, other than life insurance 12158.5 million UAH (or 94.5\%), life insurance - 704.9 million UAH (or 5.5\%). The increase in net insurance payments for 2018 (2 175.8 million UAH) was due to a significant increase in net insurance payments under insurance contracts.

Thus, the state of the insurance market, its level of integration and demand are characterized by the volume of insurance premiums and insurance payments. Of great importance in determining market stability is the level of capitalization of insurers, i.e. the amount of own funds and insurance reserves, etc. Although quantitative indicators tend to grow, the functional and institutional characteristics of Ukraine's insurance market as a whole do not meet the real needs of the economy and the aspirations of the world insurance markets, which causes its slow development in the global process of formation of the world financial system. 
Global changes in society and the rapid development of financial technologies, compounded by the growth of bank accounts, the overall volume of financial transactions and the complexity of the system of institutions and instruments involved, are determined by significant paradigm shifts both in terms of supply and demand for financial services. This is especially true for the insurance market, whose distribution of goods is highly dependent on changing moods and preferences of consumers, the emergence of new mechanisms and channels for the implementation of insurance services. In addition, the development of the world insurance market is influenced by the general economic situation in the world, crises in the financial sphere, currency fluctuations, changes in the price environment, informatization and modernization of ecosystems, increase of natural cataclysms and natural disasters, the rate of spread of the population of the planet, etc.

As a result, the insurance market is forced to respond to the outlined transformations in order to maximally meet the needs and wishes of its customers in order to protect them in terms of improving approaches to doing business, developing innovative channels of product sales and providing services and service technologies. At the same time, there are changes in the fundamentals of functioning of the world market of insurance services and organization of activity of insurance companies on it in accordance with the new paradigm of development of the economic community.

At the same time, the development of the insurance market is hampered by a number of the following problems that need to be addressed for competitive functioning of the unfavorable political and economic situation in the country; imperfect legal framework; insufficient financial support of the population; lack of public confidence in insurance companies and low level of information on the status and opportunities of the insurance market; low level of security of insurance investments; low level of capitalization of insurers; low level of responsibility for high insured risks; reinsurance of part of high risks abroad; unreasonable cash flow from Ukraine; lack of sufficient number of qualified specialists in the field; depreciation of the national currency; inability to provide longterm insurance; ineffective regulation of insurance activities by the state; lack of a clear strategy for the development of the insurance market; the role and place of insurance do not meet the challenges facing Ukraine in the current conditions of market economy formation; the current state of the insurance market does not fully meet the trends of the world insurance market.

Factors that slow down the development of insurance in Ukraine can be represented by such groups as economic, organizational-legal, functional, information-analytical and socialpsychological, the main content of which is presented in Fig. 2.

Ukraine does not have sufficient legislative framework to implement investment and compulsory health and pension insurance.

Agricultural, environmental and catastrophic risks remain underdeveloped in the insurance sector. The potential insurance market in Ukraine has significant potential for development and expansion.

The assessment of prospective vectors for the development of non-bank financial intermediaries should be made on the basis of structural modeling, which allows identifying the degree of influence of each financial institution on other participants, which allows proposing the approach involves the gradual implementation of the following steps:

1. Setting the task of researching perspective directions of development of insurance organizations and forming a list of indicators of their characteristics in the context of sectors such as non-life and life.

2. Filtering the performance characteristics of insurance companies by building a covariance matrix of input data.

3. Graphical interpretation of the model by plotting a path diagram.

4. Determination of multifactorial regression dependencies between indicators characterizing directions of development of insurance organizations. model.

5. Checking the adequacy of the structural 


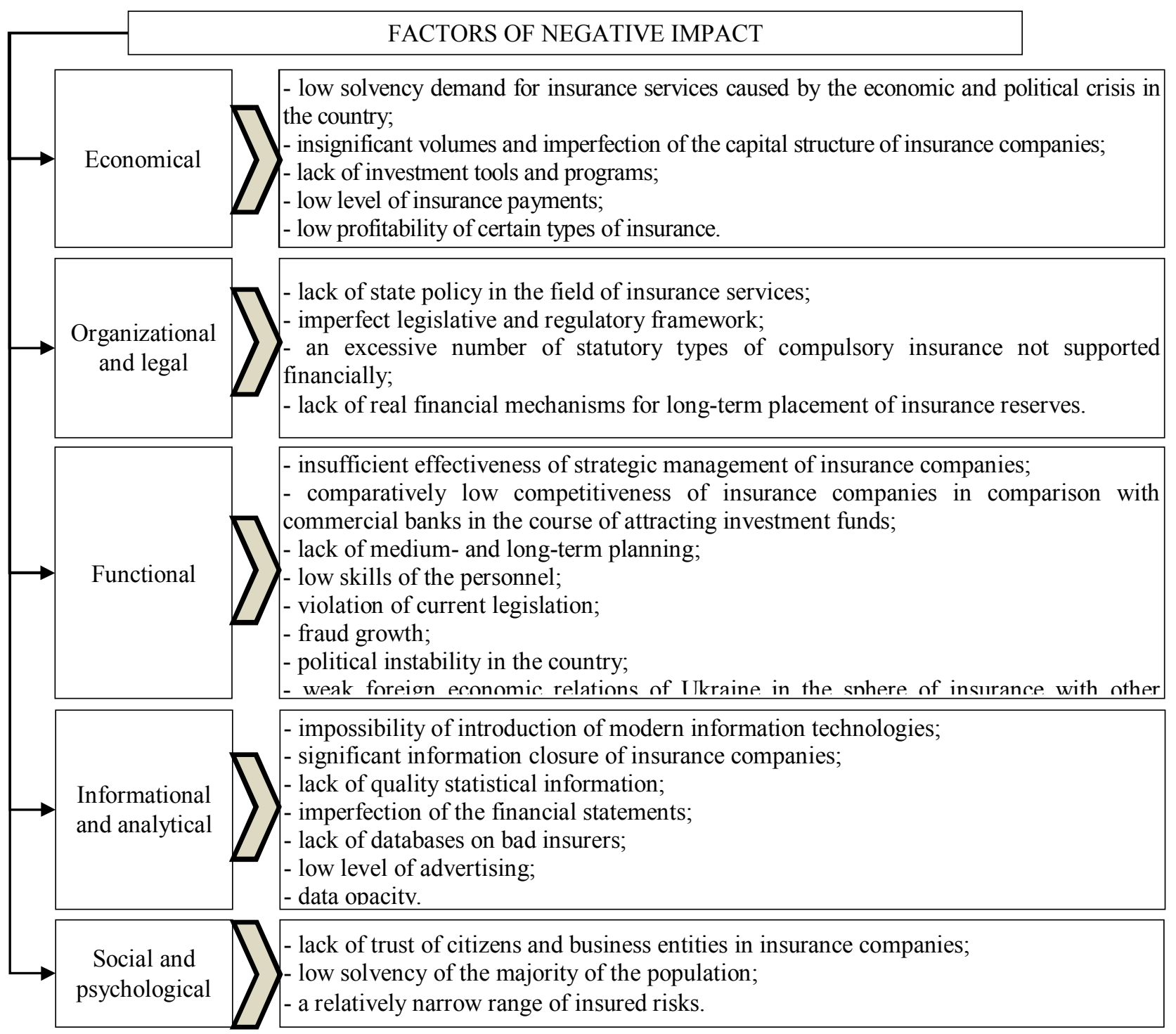

Fig. 2. Factors of negative impact on the development of the insurance market in Ukraine Source: created by the author on the base of [7].

Based on the initial data given in Table 3, correlation dependence of factors and net insurance premiums (Table 5) is established, and it is found that insurance premiums received from auto insurance $\left(\mathrm{x}_{1}\right)$, life insurance $\left(\mathrm{x}_{2}\right)$, property $\left(\mathrm{x}_{3}\right)$, unhappy have the greatest impact on the total net insurance premiums cases $\left(\mathrm{x}_{4}\right)$.
The established dependence became the basis for obtaining a statistically significant correlation-regression model of the dependence of the total amount of net insurance premiums (NIP) in the whole sphere of insurance on its individual types:

$$
N I P=0.9426 \cdot \mathrm{x}_{1}+2.2042 \cdot \mathrm{x}_{2}+2.6177 \cdot \mathrm{x}_{3}+2.4896 \cdot \mathrm{x}_{4}+3533.7735
$$

It is determined that only these factors influence the total amount of net insurance premiums in the insurance industry. The reliability of the built module is confirmed by the high value of the quadratic correlation coefficient $\left(\mathrm{R}^{2}=1.0\right)$, and the standard error is 0 .
Based on the initial data given in Table 4, there is a close correlation between almost all factors and the performance indicator (Table 6), and it is found that the net insurance premiums have the largest impact on the net insurance premiums paid on auto insurance $\left(\mathrm{x}_{1}\right)$, credit insurance $\left(\mathrm{x}_{2}\right)$, financial risks $\left(\mathrm{x}_{3}\right)$, medical expenses $\left(\mathrm{x}_{4}\right)$. 
Table 5. Correlation between factors and net insurance premiums

\begin{tabular}{|l|l|l|l|l|l|l|l|l|l|l|l|l|l|l|l|}
\hline & $\mathrm{y}$ & $\mathrm{x}_{1}$ & $\mathrm{x}_{2}$ & $\mathrm{x}_{3}$ & $\mathrm{x}_{4}$ & $\mathrm{x}_{5}$ & $\mathrm{x}_{6}$ & $\mathrm{x}_{7}$ & $\mathrm{x}_{8}$ & $\mathrm{x}_{9}$ & $\mathrm{x}_{10}$ & $\mathrm{x}_{11}$ & $\mathrm{x}_{12}$ & $\mathrm{x}_{13}$ & $\mathrm{x}_{14}$ \\
\hline $\mathrm{y}$ & 1.0000 & & & & & & & & & & & & & & \\
\hline $\mathrm{x}_{1}$ & 0.9606 & 1.0000 & & & & & & & & & & & & \\
\hline $\mathrm{x}_{2}$ & 0.6140 & 0.4990 & 1.0000 & & & & & & & & & & & \\
\hline $\mathrm{x}_{3}$ & 0.8007 & 0.6917 & 0.6554 & 1.0000 & & & & & & & & & & & \\
\hline $\mathrm{x}_{4}$ & 0.9403 & 0.9172 & 0.3691 & 0.6052 & 1.0000 & & & & & & & & & & \\
\hline $\mathrm{x}_{5}$ & -0.7316 & -0.8809 & -0.3886 & -0.3733 & -0.6863 & 1.0000 & & & & & & & & & \\
\hline $\mathrm{x}_{6}$ & 0.3995 & 0.4683 & 0.7203 & 0.4872 & 0.1098 & -0.6184 & 1.0000 & & & & & & & & \\
\hline $\mathrm{x}_{7}$ & 0.6728 & 0.7134 & -0.1172 & 0.2480 & 0.8755 & -0.5490 & -0.2613 & 1.0000 & & & & & & & \\
\hline $\mathrm{x}_{8}$ & 0.0660 & 0.0460 & -0.5775 & 0.2143 & 0.2042 & 0.2234 & -0.5556 & 0.4498 & 1.0000 & & & & & & \\
\hline $\mathrm{x}_{9}$ & 0.6230 & 0.4586 & 0.9088 & 0.5216 & 0.4926 & -0.2714 & 0.3914 & 0.0809 & -0.5200 & 1.0000 & & & & & \\
\hline $\mathrm{x}_{10}$ & 0.8461 & 0.7002 & 0.8022 & 0.9552 & 0.6630 & -0.3736 & 0.4726 & 0.2554 & 0.0194 & 0.7472 & 1.0000 & & & & \\
\hline $\mathrm{x}_{11}$ & 0.8181 & 0.8114 & 0.8670 & 0.7596 & 0.5978 & -0.7561 & 0.8412 & 0.1834 & -0.3757 & 0.6936 & 0.8094 & 1.0000 & & & \\
\hline $\mathrm{x}_{12}$ & 0.5216 & 0.5735 & -0.0697 & -0.0585 & 0.7589 & -0.5336 & -0.2797 & 0.8932 & 0.0841 & 0.2045 & 0.0560 & 0.1183 & 1.0000 & & \\
\hline $\mathrm{x}_{13}$ & -0.4894 & -0.6647 & 0.1943 & 0.0308 & -0.6688 & 0.7686 & 0.0073 & -0.8428 & -0.1534 & 0.1160 & 0.0478 & -0.2091 & -0.8475 & 1.0000 & \\
\hline $\mathrm{x}_{14}$ & 0.9639 & 0.9394 & 0.4015 & 0.7847 & 0.9535 & -0.6756 & 0.2378 & 0.7826 & 0.3206 & 0.4221 & 0.7722 & 0.6736 & 0.5505 & -0.5597 & 1.0000 \\
\hline
\end{tabular}
Source: created by the author.

y - Net insurance premiums

$\mathrm{x}_{1}$ - Auto Insurance (Comprehensive Cover, CCLI, Green $\quad \mathrm{x}_{8} \quad$ - Accident insurance Card)

$\mathrm{x}_{2} \quad$ - Life insurance

$\mathrm{x}_{3}$ - Health Insurance (Continuous Health Insurance)

$\mathrm{x}_{4} \quad$ - Property insurance

$\mathrm{x}_{5} \quad$ - Financial risk insurance

$\mathrm{x}_{6} \quad$ - Third party liability insurance

$\mathrm{x}_{7}$ - Insurance against fire and natural hazards

$\begin{array}{ll}\mathrm{x}_{8} & \text { - Accident insurance } \\ \mathrm{x}_{9} & \text { - Cargo and baggage insurance } \\ \mathrm{x}_{10} & \text { - Medical expenses insurance } \\ \mathrm{x}_{11} & \text { - Aviation insurance } \\ \mathrm{x}_{12} & \text { - Credit insurance } \\ \mathrm{x}_{13} & \text { - Transport accident insurance } \\ \mathrm{x}_{14} & \text { - Other types of insurance }\end{array}$

Table 6. Correlation between factors and net insurance payments

\begin{tabular}{|l|l|l|l|l|l|l|l|l|l|l|l|}
\hline & $\mathrm{y}$ & $\mathrm{x}_{1}$ & $\mathrm{x}_{2}$ & $\mathrm{x}_{3}$ & $\mathrm{x}_{4}$ & $\mathrm{x}_{5}$ & $\mathrm{x}_{6}$ & $\mathrm{x}_{7}$ & $\mathrm{x}_{8}$ & $\mathrm{x}_{9}$ & $\mathrm{x}_{10}$ \\
\hline $\mathrm{y}$ & 1.0000 & & & & & & & & & & \\
\hline $\mathrm{x}_{1}$ & 0.9443 & 1.0000 & & & & & & & & & \\
\hline $\mathrm{x}_{2}$ & 0.5705 & 0.7047 & 1.0000 & & & & & & & & \\
\hline $\mathrm{x}_{3}$ & 0.9241 & 0.9518 & 0.4625 & 1.0000 & & & & & & & \\
\hline $\mathrm{x}_{4}$ & 0.5154 & 0.2544 & 0.2499 & 0.1630 & 1.0000 & & & & & & \\
\hline $\mathrm{x}_{5}$ & 0.6478 & 0.3960 & 0.2830 & 0.3256 & 0.9842 & 1.0000 & & & & & \\
\hline $\mathrm{x}_{6}$ & 0.4420 & 0.3485 & -0.4184 & 0.6056 & -0.0409 & 0.0991 & 1.0000 & & & & \\
\hline $\mathrm{x}_{7}$ & 0.6995 & 0.8382 & 0.9578 & 0.6376 & 0.2039 & 0.2812 & -0.1838 & 1.0000 & & & \\
\hline $\mathrm{x}_{8}$ & 0.1622 & -0.0496 & 0.2337 & -0.2234 & 0.8778 & 0.8032 & -0.3954 & 0.1402 & 1.0000 & & \\
\hline $\mathrm{x}_{9}$ & -0.4966 & -0.4938 & -0.8638 & -0.2204 & -0.6210 & -0.6082 & 0.5179 & -0.7920 & -0.6889 & 1.0000 & \\
\hline $\mathrm{x}_{10}$ & 0.8759 & 0.7657 & 0.6116 & 0.6971 & 0.7124 & 0.7782 & 0.1385 & 0.6043 & 0.3756 & -0.6185 & 1.0000 \\
\hline
\end{tabular}

Source: created by the author.

y - Net insurance payments

$\mathrm{x}_{1}$ - Auto Insurance (Comprehensive Cover, CCLI, "Green Card")

$\mathrm{x}_{2}$ - Health Insurance (Continuous Health Insurance)

$\mathrm{x}_{3}$ - Credit insurance

$\mathrm{x}_{4}$ - Financial risk insurance

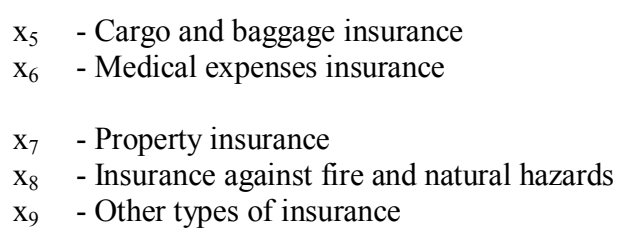

$\mathrm{x}_{5} \quad$ - Cargo and baggage insurance

$\mathrm{x}_{9} \quad$ - Other types of insurance
The established dependence became the basis for obtaining a statistically significant correlation-regression model of the dependence of the total amount of net insurance payments (NIP) on the whole sphere of insurance against its individual types:

$$
N I P=1,3259 \cdot \mathrm{x}_{1}+1,1599 \cdot \mathrm{x}_{2}+1,6617 \cdot \mathrm{x}_{3}+0,3705 \cdot \mathrm{x}_{4}+1074,6378
$$


It is found that only these factors influence the total amount of net insurance payments of the insurance industry. The reliability of the built module is confirmed by the high value of the quadratic correlation coefficient $\left(\mathrm{R}^{2}=1.0\right)$, and the standard error is 0 .

Taking into account the trends of functioning of the domestic and world markets of insurance services, and also considering the most acute problems faced by the market of insurance services of Ukraine, the model of development of the market of insurance services and in order to overcome adverse factors may become priorities in the process of promoting its development [6-11]:

-integration of the Ukrainian insurance market into the world insurance space;

-creation of institutional and infrastructure environment for insurance development;

-support of insurance entities in self organization;

- suppression of manifestations of monopolization in the insurance market;

- creation of bodies of control and supervision;

- creation of conditions that will enable insurance innovations to become the main instrument of competition;

- ensuring a high level of insurance culture of the population;

- stabilization of financial position of all economic entities due to state support of domestic business and increase of incomes and standard of living of the population;

- development of a legislative base of insurance that would take into account the current situation in the insurance market and the interests of both insurers and their clients;

-withdrawal from the market of unstable

and unreliable insurance companies, intensification of the role of the state in maintaining the competitive environment in the insurance services market;

-modernization of the branch structure and infrastructure of the insurance services market in accordance with the world requirements and leading experience of developed countries;

- creation of a modern model of effective management of insurance reserves;
- promoting the further development of reinsurance;

- development of practical marketing and obligatory organization of risk management in insurance business on the basis of training of relevant specialists.

- application of the latest technologies and introduction of innovations in insurance activity;

-implementation of international standards of insurance business;

- determination of a reliable and effective strategy of development of the insurance market of Ukraine;

- conducting public education activities to promote insurance services.

Of great importance for insurance companies is the development of a brokerage institute, the development of life insurance, personal insurance, compulsory health insurance, agrarian insurance, cyber insurance. The development of the insurance market requires that all participants are fully aware of the conditions, requirements and risks. In order to increase the level of insurance culture of citizens, it is necessary to ensure transparency of the activity of participants of this market. It should also be noted that incentives for the development of the insurance market should be provided through improvements in the tax system and the use of tax incentives [12-13].

Integration of the insurance market of Ukraine with the international markets requires increasing the competitiveness of insurers, the gradual implementation of international accounting standards and financial reporting. In order to protect the national insurance market, it is necessary to make a phased admission to the market of foreign insurers, as well as to create conditions for mutual exchange of information on the activity of insurers [14].

In the context of dynamic economic development and constant changes in regulatory standards, the IT environment for financial intermediaries is important to adapt quickly to changing conditions in order to gain competitive advantage both domestically and internationally. In Fig. 3 reflects the impact of key globalization and integration processes on the activities of insurance organizations. 


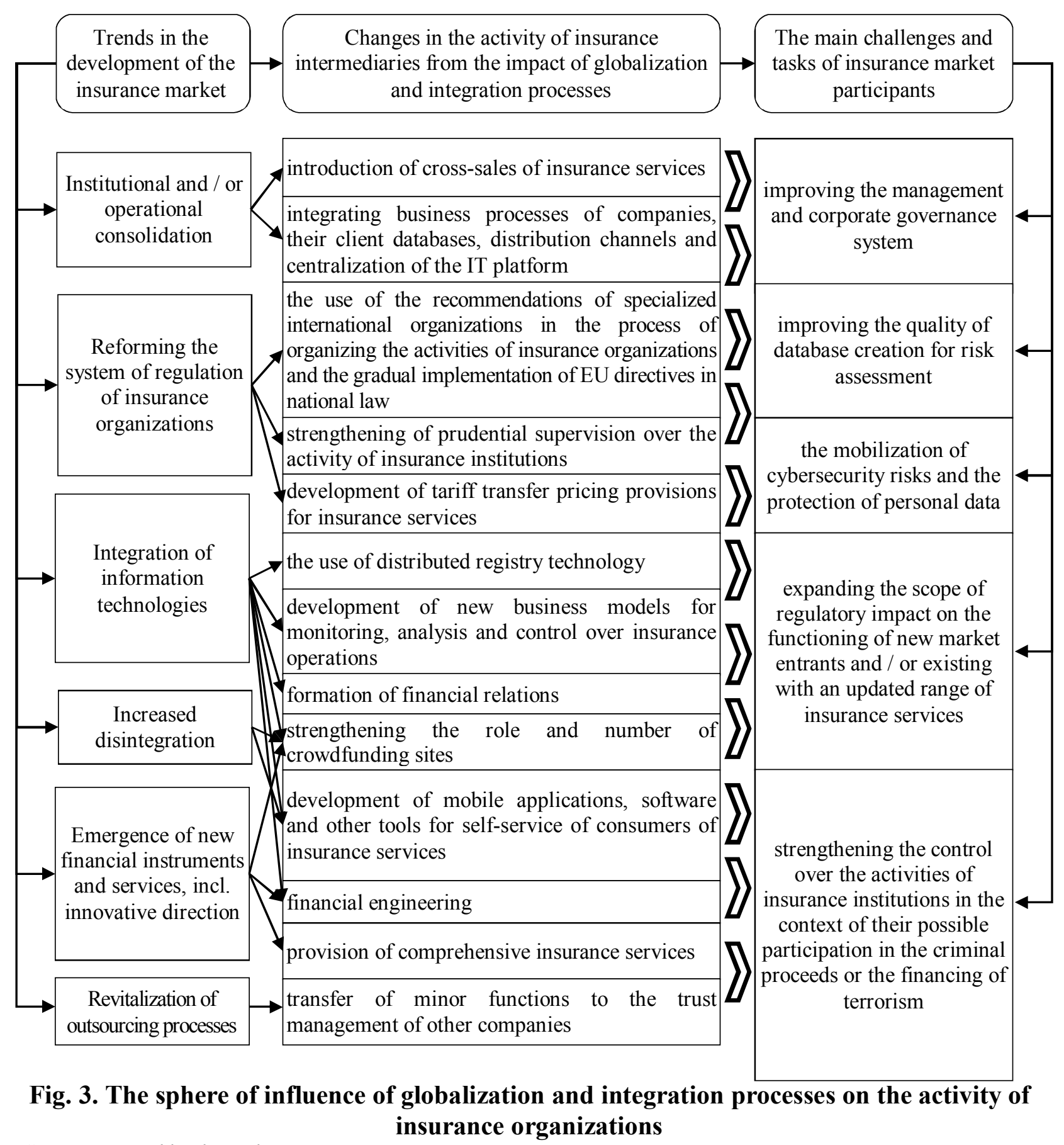

Source: created by the author.

Conclusions. On the basis of the conducted researches concerning determination of influence of globalization and integration processes on activity of insurance organizations it can be stated that the insurance market of Ukraine is at the stage of development and integration into the world space. Despite certain achievements, it is characterized by shortcomings, the presence of which shows the prospects for development and, thus, the potential for Ukraine.
Having analyzed the insurance market of Ukraine and found that it is in a difficult situation, however, there is a positive trend of its development. It is quite interesting for foreign investors, but the imperfection of legislation, low competitiveness and profitability do not allow for effective development. The Ukrainian market for insurance services continues to be seriously inferior to the main parameters of the markets of insurance services of Central and Eastern Europe. 
A large proportion of insurance in Ukraine is compulsory, but very few citizens pay for insurance on their own initiative. This is explained by both the relatively low level of income of the majority of the Ukrainian population and the low level of trust in insurance companies. The problems of development of insurance organizations are revealed and the measures for their solution in the conditions of the present with the use of correlation-regression modeling are argued. The factors that slow down the development of insurance in Ukraine are represented by such groups as economic, organizational and legal, functional, information-analytical and social- psychological. The models of dependence of the total amount of net insurance premiums and net insurance payments on the whole insurance sector on its individual types show a close correlation between almost all factors and the performance indicator. Based on these models and taking into account the trends of functioning of the domestic and world markets of insurance services, as well as taking into account the most acute problems faced by the market of insurance services of Ukraine, the priorities for promoting the development of the insurance market of Ukraine were established in order to overcome the influence of adverse factors.

\section{REFERENCES}

1. Sibirskaya, E.V., Khokhlova, O.A., Oveshnikova, L.V., \& Tulinova, E.I. (2017). Statistical research of voluntary medical insurance. Contributions to Economics, 9783319552569, $289-297$.

2. Tikhomirov, N., Tikhomirova, T., Khamitov, E., \& Ponomarev, V. (2017). Models of assessment of the influnce of insurance assets securitization on stability of mutual insurance societies. European Research Studies Journal, 20, 2, 321-333.

3. International Association of Insurance Supervisors (IAIS). (2018). Global Insurance Market Report [GIMAR]. Retrieved from https://www.iaisweb.org.

4. MARSH LLC. ALL RIGHTS RESERVED. (2018). Commercial Insurance Pricing Increased in First Quarter 2018. Retrieved from https://www.marsh.com.

5. State Statistics Service of Ukraine. (2019). Statistical information. Retrieved from https://www.nfp.gov.ua.

6. Forinsurer (2019). Results of activity of insurance companies for 2018. Retrieved from https://forinsurer.com.

7. Forinsurer (2019). Statistics of the insurance market in Ukraine. Retrieved from https://forinsurer.com/stat.

8. Baranovsky, OI (2004). Financial security in Ukraine (valuation methodology and collateral): monograph. Kyiv: Nat. trading econ. Univ.

9. Tkachenko, N. V. (2007). Reinsurance development as a lever for insurers' financial stability. Finance of Ukraine, 3, 118-123.

10. Kesan, J. P. \& Hayes, C. (2017). Strengthening cybersecurity with cyber insurance markets and better risk assessment. Minnesota law review. 102(1), 191-276.

11. SwissRe Institute (2016). World insurance in 2015: steady growth amid regional disparities. Retrieved from https://www.swissre.com.

12. Petrova, M., Tepavicharova, M., \& Boykova, L. (2017). Improvement of the efficiency and competitiveness through the implementation of benchmarking in the organizations. Bulletin of Ablai Khan KazUIRandWL, 1 (27), 5-6, 79-85.

13. Koval, V., Duginets, G., Plekhanova, O., Antonov, A., \& Petrova, M. (2019). On the supranational and national level of global value chain management. Entrepreneurship and Sustainability Issues, 6(4), 1922-1937. http://doi.org/10.9770/jesi.2019.6.4(27).

14. Labunska Sv., Petrova M., \& Prokopishyna O. (2017). Asset and cost management for innovation activity, Economic Annals - XXI, 165(5-6), 13-18. DOI: https://doi.org/10.21003/ea.V165-03. 